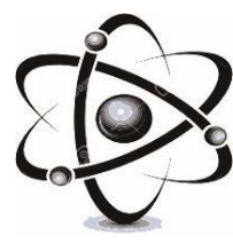

JURNAL RISET FISIKA EDUKASI DAN SAINS

Education and Science Physics Journal

E- ISSN : 2503-3425

P- ISSN : 2407-3563

JRFES Vol 3, No 2 (2017) 87 - 95

http://ejournal.stkip-pgri-sumbar.ac.id/index.php/JRFES

\title{
PENERAPAN MODEL PEMBELAJARAN KOOPERATIF TIPE STAD UNTUK MENINGKATKAN KETERAMPILAN BERFIKIR KIRTIS MAHASISWA DI STKIP PGRI SUMATERA BARAT
}

\author{
Helendra ${ }^{1}$ \\ ${ }^{1}$ Pendidikan Fisika STKIP PGRI Sumatera Barat \\ helendra@gmail.com \\ DOI: https://doi.org/10.22202/irfes.2017.v3i2.2866
}

\begin{abstract}
This study aims to develop students' thinking skills in the course of Statistics Physics The learning model used is Cooerative Model. As a teaching model, cooperative learning can be applied to learning at all levels. In this learning model, classes are organized into small groups and the lecturer provides instructions regarding the objectives to be achieved. This small group works through assignments until all groups succeed in understanding and completing the task. Cooperative learning can be applied to all tasks in various forms of curriculum.

The results showed that students' critical thinking abilities that can be developed in this learning model are: classifying, assuming, predicting, hypothesizing, evaluating, analyzing, and making conclusions. With an average value of each cycle I, cycle II and cycle III, respectively: 77.06; 81,54; and 83.64. Increasing the average value of critical thinking skills along with the increasing number of students who are in the more critical category in the hierarchy of critical thinking skills categories.
\end{abstract}

Keywords : STAD, Cooperative Learning, Critical thinking

\begin{abstract}
Abstrak
Penelitian ini bertujuan untuk mengembangkan kemampuan berpikir mahasiswa pada mata kuliah Fisika Statistik Model pembelajaran yang digunakan adalah Cooerative Model .

Sebagai sebuah model pengajaran, pembelajaran kooperatif dapat diterapkan pada Pembelajaran di semua level. Pada model pembelajaran ini, kelas diatur ke dalam kelompok-kelompok kecil dan dosen memberikan petunjuk berkenaan dengan tujuan yang hendak dicapai. Kelompok kecil ini bekerja melalui tugas hingga semua kelompok berhasil memahami dan menyelesaikan tugas tersebut. Pembelajaran kooperatif dapat diterapkan pada semua tugas dalam berbagai macam bentuk kurikulum. Hasil penelitian menunjukkan kemampuan berpikir kritis mahasiswa yang dapat dikembangkan pada model pembelajaran ini adalah: mengklasifikasi, mengasumsi, memprediksi, menghipotesis, mengevaluasi, menganalisis, dan membuat kesimpulan. Dengan nilai rata-rata tiap siklus I, siklus II dan siklus III, berturut-turut: 77,06; 81,54; dan 83,64. Peningkatan nilai rata-rata kemampuan berpikir kritis seiring dengan meningkatnya jumlah mahasiswa yang termasuk kategori lebih kritis dalam hierarki kategori kemampuan berpikir kritis.
\end{abstract}

Kata kunci : STAD, Pembelajaran kooperatif, Berfikir kritis 


\section{PENDAHULUAN}

Pada suatu pembelajaran , model pembelajaran sangatlah penting karena berpengaruh terhadap tingkat layanan dan kwalitas belajar mahasiswa. Pada dasarnya model pembelajaran bisa diberikan agar mahasiswa bisa terbantu untuk lebih fokus pada topik utama dalam setiap perkuliahan. Model pembelajaran merupakan salah satu variasi belajar yang bisa digunakan oleh mahasiswa untuk berdiskusi dengan temannya ataupun juga dengan dosen.

Selain dari itu untuk mendapatkan kwalitas pembelajaran yang baik, dosen juga harus bisa bertindak sebagai motivator dan fasilitator dalam pembelajaran. Dengan itu diharapkan bisa terciptakan kondisi pembelajaran yang aktif, kreatif dan mandiri sehingga tercipta interaksi yang baik antara mahasiswa dengan dosen maupun antara mahasiswa dengan sesamanya. Mahasiswa dilatih untuk dapat membangun pemahamannya sendiri tanpa bergantung pada dosen.

Dari hasil analisis prelminary sebelumnya yaitu dengan pengajaran tanpa adanya variasi cara mengajar pada mahasiswa, ternyata mahasiswa cendrung cepat bosan, kurang termotivasi dan tidak tertarik untuk mengeksplorasi lebih jauh materi yang diajarkan yang dapat berpotensi menurunkan kemampuan hardskill mahasiswa.

Dengan penelitian ini diharapkan akan diperoleh suatu model pembelajaran yang sesuai untuk mata kuliah yang relevan untuk bisa menumbuh kembangkan kemampuan berfikir kritis, penalaran, dan komunikasi ilmiah mahasiswa seperti yang diharapkan dalam Kurikulum 2013. Pada penelitian ini dirancang suatu model pembelajaran yang terpusat kepada siswa (Student Centre Learning) yang bisa mengantisipasi kejenuhan peserta didik terhadap metode ceramah.

Salah satu metode pembelajaran yang berpusat kepada siswa (Student Centre Learning) adalah pembelajaran kooperatif (Dewajani, 2008). Pembelajaran kooperatif adalah belajar bersama-sama, saling membantu antara satu dengan yang lain dalam belajar dan memastikan bahwa setiap orang dalam kelompok mencapai tujuan atau tugas yang telah ditetapkan. Cooperative learning berasal dari kata cooperative yang artinya mengerjakan sesuatu secara bersama-sama dengan saling membantu satu sama lainnya sebagai satu kelompok atau satu tim. Slavin (1995) mengemuka $\neg$ kan, "In cooperative learning methods, students work together in four member teams to master material initially presented by the 
teacher". Dari uraian tersebut dapat dikemukakan bahwa cooperative learning adalah suatu model pembelajaran dimana sistem belajar dan bekerja dalam kelompokkelompok kecil yang berjumlah 4-6 orang secara kolaboratif sehingga dapat merangsang mahasiswa lebih bergairah dalam belajar.

Falsafah yang mendasari model pembelajaran kooperatif adalah falsafah homo homini socius yaitu menekankan bahwa manusia adalah makhluk sosial, kerja sama merupakan kebutuhan yang sangat penting artinya bagi kelangsungan hidup.

Metode pembelajaran cooperative learning mempunyai manfaat yang positif apabila diterapkan di ruang kelas. Beberapa keuntungannya antara lain: mengajarkan mahasiswa untuk percaya pada guru, memacu kemampuan mahasiswa untuk berfikir, mencari informasi dari sumber lain dan belajar dari mahasiswa lain; mendorong mahasiswa untuk mengungkapkan idenya secara verbal dan membandingkan dengan ide temannya; dan membantu mahasiswa belajar menghormati mahasiswa yang pintar dan mahasiswa yang lemah juga menerima perbedaan ini. Ironisnya, model pembelajaran kooperatif belum banyak diterapkan dalam pendidikan walaupun orang
Indonesia sangat membanggakan sifat gotong royong dalam kehidupan bermasyarakat.

Student Team Achievement Division (STAD) merupakan salah satu metode pembelajaran kooperatif yang paling sederhana, dan merupakan model yang paling baik untuk para guru atau dosen yang baru menggunakan pola pendekatan kooperatif. Dalam pelaksanaannya, pembelajaran kooperatif tipe STAD memiliki kelebihan dan kekurangan, di antara kelebihannya, yaitu:

1) Dapat memberikan kesempatan kepada mahasiswa untuk bekerjasama dengan mahasiswa lain,

2) Mahasiswa dapat menguasai pelajaran yang disampaikan,

3) Setiap anggota mahasiswa berhak menjadi ahli dalam kelompoknya,

4) Dalam proses belajar mengajar mahasiswa saling ketergantungan positif,

5) Setiap mahasiswa dapat saling mengisi satu sama lain.

\section{METODE PENELITIAN}

Kategori untuk penelitian ini bersifat action research dengan konsep yang disusun untuk penelitian ini adalah mengacu kepada penelitian tindakan kelas. Model penelitian tindakan kelas yang banyak digunakan di Indonesia adalah model siklus yang 
dikemukakan oleh Kemmis dan MacTaggart (Amirin,2009).

Secara umum tahapan penelitian dirancang dengan mengikuti model Kemmis dan MacTaggart ini yang dibagi dalam 5 tahapan utama yaitu : Tahap I Perencanaan (Planning) draf desain kooperatif tipe STAD, Tahap II Tindakan dan Pengamatan (Action \& Observation) penerapan draf, Tahap III Analisis hasil dan Perencanaan Ulang untuk perbaikan draf kooperatif tipe STAD (Reflecting \& Replanning), Tahap IV Tindakan dan Pengamatan (Action \& Observation) penerapan draf desain kooperatif tipe STAD yang telah diperbaiki, Tahap V Analisis Akhir Penelitian (Reflecting), dimana akan dilakukan perbaikan kembali atas desain kooperatif jika masih dibutuhkan sesuai dengan hasil analisis evaluasi .

Sebelum tahap perencanaan perlu dilakukan identifikasi permasalahan. Hasil observasi awal di salah satu kelas di program studi Pendidikan Fisika serta wawancara dengan para mahasiswanya menunjukkan kemampuan pemecahan masalah pada kelas tersebut masih rendah. Setelah merumuskan permasalah yang ada kemudian peneliti merencanakan penerapan model pembelajaran kooperatif tipe STAD. Hal yang perlu dipersiapkan untuk mengatasi masalah tersebut adalah pembuatan instrumen pembelajaran. Intrumen tersebut berupa Rencana Pelaksanaan Pembelajaran (RPP), tugas membaca, soal untuk lembar ahli, lembar observasi dan soal evaluasi akhir siklus. Pelaksanaan pembelajaran dilakukan sesuai dengan rencana pelaksanaan pembelajaran yang telah disusun sebelumnya. Materi yang dipelajari berbeda pada setiap siklusnya. Kegiatan evaluasi dilakukan oleh peneliti dan observer yang merupakan salah satu dosen. Setiap akhir siklus dilaksanakan refleksi dan evaluasi. Refleksi adalah mengkaji kembali semua kegiatan yang telah dilakukan pada pembelajaran kooperatif tipe STAD. Hasil refleksi kemudian digunakan untuk mengetahui sejauh mana pelaksanaan tindakan mencapai sasaran. Hasil evaluasi digunakan untuk merencanakan perbaikan pada siklus berikutnya. Secara sistematis penelitian tindakan kelas yang dilakukan seperti pada Gambar1.

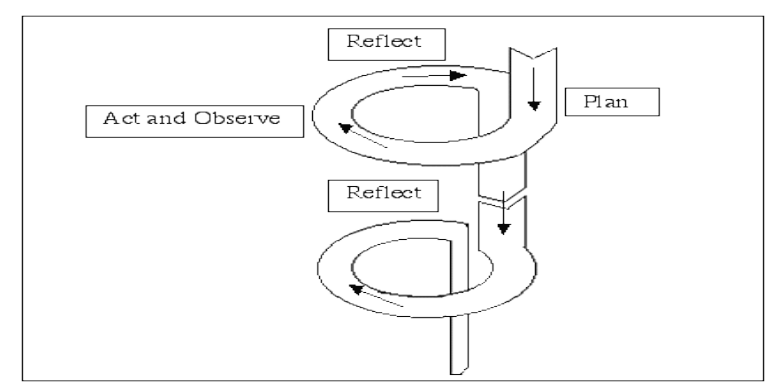

\section{Instrumen Penelitian}


Instrumen yang digunakan dalam penelitian ini adalah lembar observasi untuk menilai peningkatan kognitif di setiap siklusnya dan angket disusun berdasarkan skala Likert.

\section{Teknik Analisis Data}

1. Analisis kemampuan berfikir kritis Analisis kemampuan mahasiswa dengan model pembelajaran dilakukan dengan analisis aktifitas berdasarkan lembar observasi serta hasil belajar mahasiswa. Perhitungan nilai akhir hasil efektivitas juga dinyatakan dalam skala ( $1-100)$ menggunakan rumusan :

$$
E=\frac{f}{n} \times 100 \%
$$

\section{Keterangan :}

$\mathrm{E}=$ Presentase kemampuan berfikir kritis mahasiswa

$\mathrm{f}=$ Jumlah mahasiswa terlibat $\mathrm{n}=$ Jumlah mahasiswa yang hadir

Kategori analisa kemampuan mahasiswa dengan model pembelajaran ini berdasarkan nilai akhir yang didapatkan dan dapat dilihat pada table berikut :

\begin{tabular}{|c|c|}
\hline Interval & Kategori \\
\hline $0-20$ & Tidak Kritis \\
\hline $21-40$ & Kurang Kritis \\
\hline $41-60$ & Cukup Kritis \\
\hline $61-80$ & Kritis \\
\hline $81-100$ & Sangat Kritis \\
\hline
\end{tabular}

Tabel 1. Interval berfikir kritis mahasiswa dengan model pembelajaran

\section{HASIL DAN PEMBAHASAN}

Dalam pelaksanaan Model Pembelajaran Kooperatif Tipe STAD untuk peningkatan ketrampilan berfikir kritis, masalah adalah sebagai berikut: Sebelum dilaksanakan pembelajaran kooperatif tipe STAD disusun beberapa instrumen berupa: Rencana Pelaksanaan Pembelajaran (RPP), soal-soal tugas membaca, soal-soal lembar ahli, soal evaluasi akhir siklus dan lembar keaktifan siswa. Untuk meningkatkan kerampilan berfikir kritis dalam pembelajaran kooperatif tipe STAD dilakukan pemberian soal yang bertujuan meningkatkan kemampuan nalar soal. Soal-soal tersebut diberikan sebelum pelaksanaan pembelajaran di kelas, yakni pekerjaan rumah, saat siswa berdiskusi kelompok di kelas dan saat tes akhir siklus. Soal-soal yang diberikan dalam langkah tersebut berupa soal uraian. Lembar keaktifan digunakan untuk mengukur hasil belajar afektif siswa selama proses pembelajaran. 
Lembar keaktifan diisi oleh observer, yaitu dosen fisika. Selain lembar keaktifan mahasiswa, hasil belajar kognitif mahasiswa juga diobservasi. Observasi tersebut digunakan sebagai indikator hasil belajar kognitif siswa secara klasikal dan dilakukan setelah pembelajaran selesai. Usaha yang dilakukan guru untuk meningkatkan kemampuan berfikir kritis mahasiswa adalah mengusahakan pemberian soal-soal yang berisi kemampuan pemecahan masalah dengan menggunakan bahasa yang mudah dimengerti mahasiswa dan isinya pun disesuaikan dengan materi yang dipelajari. Mahasiswa juga selalu diingatkan untuk mengerjakan tugas membaca agar sebelum pelaksanaan pembelajaran para mahasiswa sudah mempunyai pengetahuan awal. Saat pelaksanaan diskusi, mahasiswa juga mendapat pengarahan oleh dosen. Apabila saat diskusi mahasiswa mulai sibuk dengan kegiatan yang tidak berhubungan dengan diskusi maka mahasiswa diingatkan oleh dosen agar kembali berdiskusi dengan baik. Untuk mengetahui gambaran persentase kemampuan pemecahan masalah siswa sebagai kemampuan kognitif mahasiswa dapat dilihat pada Tabel 1. Berdasarkan uji $\mathrm{t}$ (dibandingkan dengan hasil siklus selanjutnya) yang dilakukan pada tiap akhir siklus diperoleh peningkatan hasil belajar kognitif mahasiswa yang signifikan dari siklus ke siklus.

Kemampuan berfikir kritis yang merupakan hasil belajar kognitif mengalami peningkatan setelah menerapkan model pembelajaran kooperatif tipe STAD dan memenuhi indikator keberhasilan. Segala sesuatunya tentang analisis tes kemampuan berpikir kritis mahasiswa disajikan pada Tabel 2 berikut : Tabel 2 ; Kemampuan Berfikir Kritis

\begin{tabular}{c|lcccc}
\hline \multirow{2}{*}{ No } & \multirow{2}{*}{ Kemampuan } & Siklus 1 & Siklus 2 & Siklus 3 \\
\cline { 3 - 5 } & & Rata rata tiap aspek & Rata rata tiap aspek & Rata rata tiap aspek \\
\hline 1 & Mengklasifikasi & 78,2 & 83.4 & 84,6 \\
\hline 2 & Mengasumsi & 73,1 & 79,2 & 82 \\
\hline 3 & Menganalisis & 79,5 & 83,2 & 83,8 \\
\hline 4 & Menyimpulkan & 79,5 & 84,3 & 88,5 \\
\hline 5 & Mengevaluasi & 75 & 77,6 & 79,3 \\
\hline & Rata rata & $\mathbf{7 7 , 0 6}$ & $\mathbf{8 1 , 5 4}$ & $\mathbf{8 3 , 6 4}$ \\
\hline
\end{tabular}


Penilaian ini berdasarkan tes kemampuan berpikir yang diadakan disetiap akhir pembelajaran dari masing masing siklus. Hasil penilaian ini dikategorikan seperti disajikan pada Tabel 3 berikut :

Tabel 3: Hasil penilaian berfikir kritis.

\begin{tabular}{|l|c|c|c|c|c|c|}
\hline \multirow{2}{*}{ Kategori } & \multicolumn{2}{|c|}{ Siklus 1 } & \multicolumn{2}{c|}{ Siklus 2 } & \multicolumn{2}{c|}{ Siklus 3 } \\
\cline { 2 - 7 } & $\begin{array}{c}\text { Jumlah } \\
\text { mahasiswa }\end{array}$ & $\begin{array}{c}\text { Nilai } \\
\text { ratarata }\end{array}$ & $\begin{array}{c}\text { Jumlah } \\
\text { mahasiswa }\end{array}$ & $\begin{array}{c}\text { Nilai } \\
\text { ratarata }\end{array}$ & $\begin{array}{c}\text { Jumlah } \\
\text { mahasiswa }\end{array}$ & $\begin{array}{c}\text { Nilai } \\
\text { ratarata }\end{array}$ \\
\hline Tidak Kritis & 1 & - & - & - & - & - \\
\hline Kurang Kritis & 7 & 25,6 & 7 & 26,8 & 4 & 25,1 \\
\hline Cukup Kritis & 10 & 46,4 & 9 & 55,7 & 7 & 56,9 \\
\hline Kritis & 2 & 65,2 & 4 & 73,5 & 8 & 75,1 \\
\hline Sangat Kritis & - & - & - & - & 1 & 84,3 \\
\hline
\end{tabular}

Kemampuan berpikir kritis merupakan salah satu modal dasar atau modal intelektual yang sangat penting bagi setiap orang, selain itu menurut Penner dalam Ibrahim (2007) kemampuan ini merupakan bagian yang fundamental dalam kematangan manusia. Berpikir kritis adalah berpikir secara beralasan dan reflektif dengan menekankan pembuatan keputusan tentang apa yang harus dipercayai dan dilakukan (Hassoubah, 2002:85). Berpikir kritis merupakan kegiatan menganalisis ide atau gagasan ke arah yang lebih spesifik, membedakan secara tajam, memilih, mengidentifikasi, mengkaji dan mengembangkannya ke arah yang lebih sempurna. Proses mental ini menganalisis ide dan informasi yang diperoleh dari hasil pengamatan, pengalaman, akal sehat atau komunikasi. Orang yang berpikir kritis akan mengevaluasi dan kemudian menyimpulkan suatu hal berdasarkan fakta untuk membuat keputusan. Menurut Hassoubah (2002:111) salah satu ciri orang yang berpikir kritis akan selalu mencari dan memaparkan hubungan antara masalah yang didiskusikan dengan masalah atau pengalaman lain yang relevan. Kategori berpikir kritis menurut Carin\&Sund, yaitu : 1) mengklasifikasi; 2) mengasumsi; 3) memprediksi dan hipotesis; 4) menginterpretasi data, mengiferensi atau membuat kesimpulan; 5) mengukur; 6) merancang sebuah penyelidikan; 7) mengamati; 8) membuat grafik; 9) meminimalkan kesalahan percobaan; 10) mengevaluasi; dan 11) menganalisis (Carin \& Sund 1998:160). Pelaksanaan penerapan 
model pembelajaran kooperatif ini dapat meningkatkan hasil belajar mahasiswa. Peningkatan kemampuan berpikir kritis mahasiswa dari siklus I ke II dan ke III juga mengalami peningkatan. Penentuan kemampuan berpikir kritis yang dikaji dalam penelitian ini disesuaikan dengan tahap perkembangan kognitif mahasiswa, model pembelajaran Kooperatif, dan materi perkuliahan. Peningkatan kemampuan berpikir kritis dari siklus I ke II serta ke III disebabkan karena mahasiswa sudah mulai terbiasa dengan pembiasaan berpikir kritis dalam memecahkan disetiap pembelajaran. Hal ini sesuai dengan pendapat yang menyatakan bahwa pembiasaan berpikir kritis secara bertahap memiliki kecenderungan membuat mahasiswa semakin memandang berbagai hal disekitarnya dengan rasa ingin tahu, sehingga ada pemberian makna.

\section{KESIMPULAN}

Kemampuan berpikir kritis seorang mahasiswa akan sangat membantu dalam mengambil keputusan secara tepat, cermat, sistematis, benar dan logis, dengan mempertimbangkan berbagai sudut pandang atau aspek (Suprapto, 2007). Keputusan inilah yang dijadikan sebagai solusi dari suatu permasalahan. Solusi permasalahan didiskusikan kembali bersama teman dan dosen Pengetahuan yang telah diperoleh selama pembelajaran dievaluasi dengan soalsoal yang berkaitan dengan materi tersebut disetiap akhir pembelajaran. Dengan demikian kemampuan berpikir kritis merupakan perpaduan dari kemampuan kemampuan saintis ketika melakukan penelitian ilmiah. Kemampuan ini menjadi roda penggerak penemuan dan dan pengembangan fakta dan konsep serta penumbuhan dan pengembangan sikap dan nilai. Hal ini sesuai dengan pendapat Semiawan, bahwa seluruh irama gerak atau tindakan dalam proses belajar mengajar akan menciptakan kondisi cara belajar siswa aktif (Hamalik,1998:149). Peningkatan nilai ratarata kemampuan berpikir kritis seiring dengan meningkatnya jumlah mahasiswa yang termasuk kategori sangat kritis dan kritis dalam hierarki kategori kemampuan berpikir kritis. Dari hasil penelitian terlihat jelas bahwa pada dasarnya mahasiswa mempunyai potensi kemampuan berpikir kritis. Potensi ini sangat disayangkan jika tidak dapat dikembangkan dengan baik. Melalui penerapan model pembelajaran kooperatif tipe STAD ini, mahasiswa dapat mengembangkan kemampuan berpikir kritis dan kemampuan pemecahan masalah. Model sebagai model pengajaran yang digunakan untuk melatih kemampuan memecahkan masalah yang dialami mahasiswa dalam kehidupan 
seharihari secara berkelompok, memberikan penguasaan konsep yang lebih tinggi. Hal ini sesuai dengan pembelajaran aktif dalam pengajaran kontruktivisme (Doppelt, 2003), yaitu mahasiswa akan lebih mudah menemukan dan memahami konsep melalui pemikiran aktif dan pemecahan masalah tidak hanya sekedar mengingat melainkan melakukan kegiatan membangun pengetahuan dengan latihan dari dosen atau pekerjaan rumah yang terdapat pada buku.

\section{DAFTAR PUSTAKA}

Budiman, I, Sukandi, A, Setiawan, A. 2008. Model Pembelajaran Multimedia Interaktif Dualisme Gelombang Partikel untuk Meningkatkan Pemahaman Konsep dan Ketertampilan Berfikir Kritis. Jurnal Penelitian Pendidikan IPA (2) 1 Bandung, S.Ps UPI

Amirin, Tatang M. (2009). Classroom action research (penelitian tindakan kelas), diunduh di http://www.tatangmanguny.files.wo rdpress.com/2009/05/kemmismctaggart-ar-cycles1.gif, Sabtu, 14 April 2012

Amien, M. (1987). Mengajar ilmu pengetahuan alam (IPA) dengan menggunakan metode discavery dan inquiry. Jakarta: Depdikbud, Dirjen Dilti PPLPTK. Cafrey

Buku Panduan Penyusunan Kurikulum Pendidikan Tinggi (KPT), Direktoran Pembelajaran dan Kemahasiswaan, Direktorat Jenderal Pendididkan Tinggi, 2012

Media Pendidikan Indonesia (2012), Desain PTK Model Kemmis \& McTaggart, Copyright : www.m-edukasi.web.id, diunduh Sabtu, 14 April 2012, di http://www.medukasi.web.id/2012/04/desain-ptkmodel-kemmis-mctaggart.html

Kepmen No 232/U/2000 Tentang Pedoman Penyusunan Kurikulum Pendidikan Tinggi dan Penilaian Hasil Belajar Mahasiswa

Perpres No. 8 Tahun 2012 tentang Kerangka Kualifikasi Nasional Indonesia (KKNI)

Rahmat, 2011, Lokakarya Pengembangan Kurikulum Berbasis Kompetensi, Universitas Diponegoro, http://eprints.undip.ac.id/28581/ 